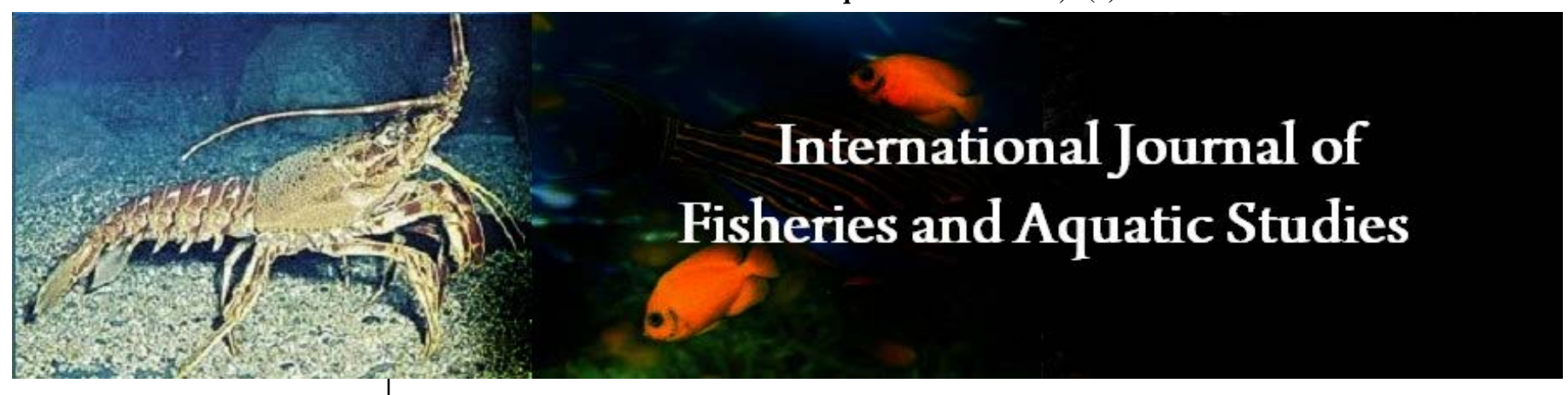

E-ISSN: 2347-5129

P-ISSN: 2394-0506

(ICV-Poland) Impact Value: 5.62

(GIF) Impact Factor: 0.549

IJFAS 2021; 9(2): 60-65

(C) 2021 IJFAS

www.fisheriesjournal.com

Received: 26-01-2021

Accepted: 27-02-2021

\section{Afiefah Salsabila}

Jl. Raya Bandung Sumedang,

KM 21, Hegarmanah,

Jatinangor, Sumedang, Faculty

of Fisheries and Marine Science,

Padjadjaran University West

Java, Indonesia

\section{Zahidah}

Jl. Raya Bandung Sumedang,

KM 21, Hegarmanah,

Jatinangor, Sumedang, Faculty

of Fisheries and Marine Science,

Padjadjaran University West

Java, Indonesia

\section{Walim Lili}

Jl. Raya Bandung Sumedang,

KM 21, Hegarmanah,

Jatinangor, Sumedang, Faculty

of Fisheries and Marine Science,

Padjadjaran University West

Java, Indonesia

\section{Herman Hamdani}

Jl. Raya Bandung Sumedang,

KM 21, Hegarmanah,

Jatinangor, Sumedang, Faculty

of Fisheries and Marine Science,

Padjadjaran University West

Java, Indonesia

Ine Maulina

Jl. Raya Bandung Sumedang,

KM 21, Hegarmanah,

Jatinangor, Sumedang, Faculty of Fisheries and Marine Science,

Padjadjaran University West

Java, Indonesia

Corresponding Author:

Afiefah Salsabila

Jl. Raya Bandung Sumedang,

KM 21, Hegarmanah,

Jatinangor, Sumedang, Faculty

of Fisheries and Marine Science,

Padjadjaran University West

Java, Indonesia

\section{Upstream Citarum river water status based on periphyton saprobic index}

\author{
Afiefah Salsabila, Zahidah, Walim Lili, Herman Hamdani, and Ine \\ Maulina
}

DOI: https://doi.org/10.22271/fish.2021.v9.i2a.2444

\section{Abstract}

The research aims to determine the status of the waters in the Citarum River section upstream by using the periphyton saprobic index as bio-indicators of water. This research was conducted from 13 August 2020 - 25 November 2020. The method of research using the method of survey and collection of samples is done by purposive sampling, a method of retrieval of data tailored to the needs of research. This research was conducted at 4 stations with 6 replications every 7 days. The results showed that during the research in the Citarum River there were 24 genera of periphyton communities divided into 4 classes, namely Cyanophyceae, Bacillariophyceae, Chlorophyceae, and Euglenophyceae. The periphyton saprobic index values ranged from 0,69 to 1,00. It indicates that the status of the Citarum River part of the upstream experience level of contamination mild by category $\beta$ - Mesosaprobic and the range of indices by $0,5-1,0$.

Keywords: Water Pollution Level, Upstream Citarum River, periphyton, index saprobic

\section{Introduction}

The Citarum River is the longest and largest river in West Java Province. Upstream Citarum River is contained in Gunung Wayang south of Bandung and empties in the Sea of Java. The Citarum River streams along $297 \mathrm{~km}$ by crossing 10 districts and 2 cities in West Java. The use of the Citarum River to support various activities and human life as a source of water means of transportation, power generation, irrigation, industrial needs, tourism, and fisheries development ${ }^{[1]}$.

The more to the direction of downstream, the river experienced a decline in the quality of water due to changes in activities of anthropogenic which makes the river as place disposal of waste either of activities home household or industrial. The problem of pollution caused by the activities of man as clearing land for agriculture, the development of urban and industrial, felling timber and mining in the area of catchment water or the area stream (DAS) as well as waste home household who live in the area the stream of the river ${ }^{[2]}$.

Periphyton is a collection of microorganisms that grow and attach to the substrate. Periphyton

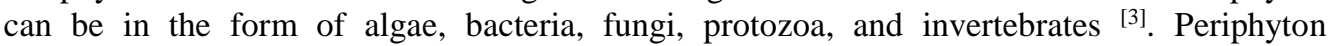
relatively does not move, then the abundance and composition of periphyton in waters affected by the quality of waters where his life ${ }^{[4]}$. Periphyton can be used as a bioindicator in seeing the quality of water.

Index saprobic is an index that is used to determine the status of contamination of organic in water. The index is using the presence of organisms that are present in the water to determine the status of waters ${ }^{[5]}$. Material pollutants with the index saprobic can be connected to the level of pollution of waters ${ }^{[6]}$. This research aims to determine the status of the waters in the upper Citarum River by using periphyton as a water bio-indicator.

\section{Materials and Methods}

\subsection{Study area}

This research was conducted from 13 August 2020 - 25 November 2020. The activities of research consist of studies insitu and research exsitu. Insitu measurements consist of measurements of temperature, light transparency, stream, pH, DO, and CO2. 
While measurement is exsitu consists of measuring BOD, nitrates, and phosphates. The research method used a survey method and the sample was taken by purposive sampling. There are four stations the location of taking the samples and performed a total of six repetitions every 7 days wipe li with time taking samples to differ in each of the stations. The locations of the research stations are:

Station 1: Situ Cisanti, namely section outlet where the coordinates of taking samples of $7^{\circ} 12^{\prime} 29$ "LS 107³9'33"BT, surrounding land use is primary forest.

Station 2: Wangisagara, to coordinate retrieval of samples $7^{\circ} 4^{\prime} 54^{\prime \prime} \mathrm{LS} 107^{\circ} 44^{\prime} 20^{\prime \prime} \mathrm{BT}$, surrounding land use is the area of residential and land farming.

Station 3: Majalaya, to coordinate retrieval of samples $7^{\circ} 3^{\prime} 4^{\prime L S} 107^{\circ} 45^{\prime} 24^{\prime \prime} \mathrm{E}$, surrounding land use is the area of the residential and industrial area.

Station 4: Sapan, to coordinate retrieval of samples $7^{\circ} 0^{\prime} 8$ "LS $107^{\circ} 43^{\prime} 12^{\prime B T}$, surrounding land use is the area of the residential, agricultural and industrial area. The following is an overview of the map of the research location shown in (Figure 1)

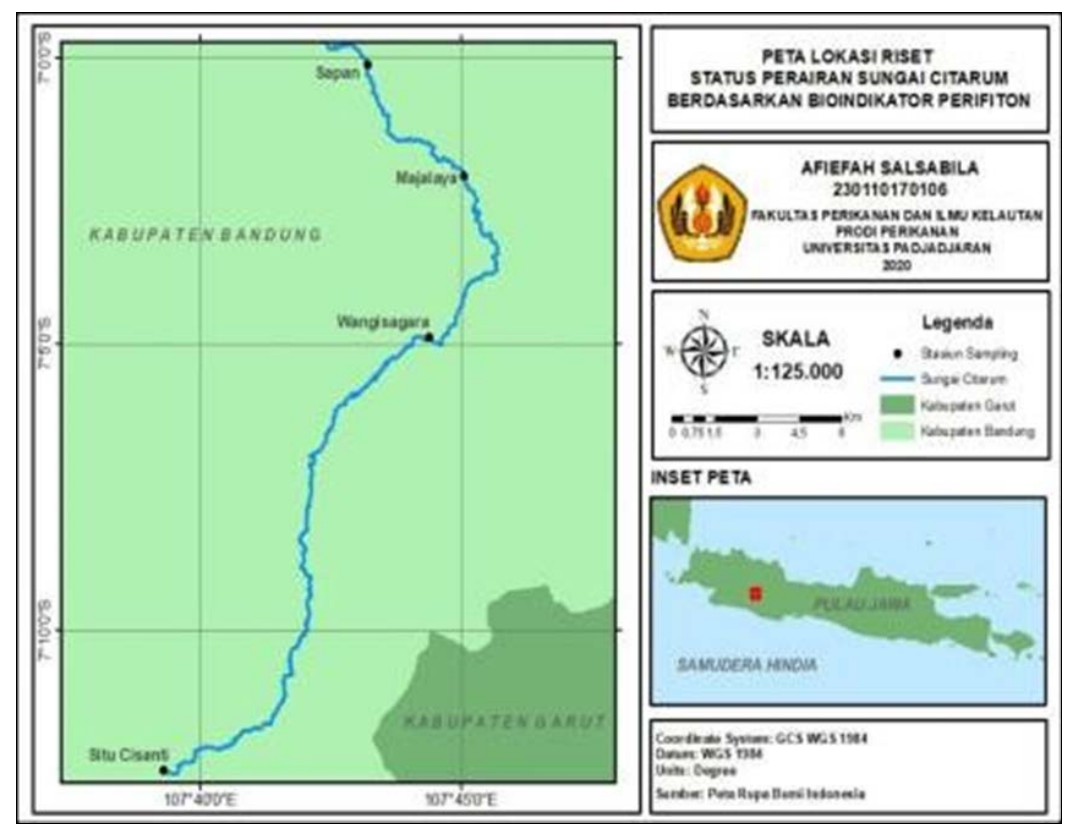

Fig 1: Map of the Research Location

\subsection{Data collection}

The tools used in this study were a 50 x $10 \mathrm{~cm}$ pipe, brush, mine, sample bottle, plankton net, scoop, cool box, $\mathrm{pH}$ meter, DO meter, thermometer, Secchi disk, camera, dipper, pipette, microscope, counting chamber, periphyton identification book, cover glass, volume pipette, spectrophotometer, Erlenmeyer, burette, spatula, filter paper. The materials used for the study were: samples of Citarum waters, 1\% Lugol, MnSO4; H2SO4; Sodium thiosulfate; O2 reagent, Disulfonic Phenolic Acid (10\% NH4OH), SnCl2 (NH4-molybdate) Reducing Solution, Citarum River periphyton sample.

Periphyton taken is the one that attaches to the substrate made with $50 \mathrm{~cm}$ PVC pipe substrate that has been soaked for 1 week at each station on the Citarum River. After soaking, pipe in a lift and swept by using a brush on the surface of the PVC pipe. The results of the sweep that has been obtained were then thawed with distilled water and filtered by using a plankton net. Furthermore, it is put into the sample bottle and preserved using 1\% Lugol until the sample is yellow.

The saprobic index will describe the amount of pollutant load that occurs in the ecosystem in the study area.

$X=\frac{C+3 D-B-3 A}{A+B+C+D}$

$\mathrm{X}=$ Saprobic Index

$A=$ Number of Species Organisms Polysaprobik

$\mathrm{B}=$ Number of species of organisms $\alpha$ - Mesosaprobic

$\mathrm{C}=$ Number of species of organisms $\beta$ - Mesosaprobic

$\mathrm{D}=$ Number of Species Organisms Oligosaprobik

Diversity index and saprobic index can be related to the level of saprobity and pollution conditions of water as presented in (Table 1) below.

Table 1. The Relationship Between Water Saprobity Index and Pollution Level.

\begin{tabular}{|c|c|c|c|}
\hline materials Pollutants & Pollutant Level & Saprobity level & Saprobity Index \\
\hline \multirow{2}{*}{$\begin{array}{c}\text { Organic } \\
\text { Ingredients }\end{array}$} & Very Heavy & Polisaprobik & -3.0 up to -2.0 \\
\cline { 2 - 4 } & Quite Heavy & Poli / $\alpha-$ Meso saprobic & -2.0 up to -1.5 \\
\hline & & $\alpha-$ Meso / Poli saprobic & -1.5 up to -1.0 \\
\hline \multirow{2}{*}{$\begin{array}{c}\text { Organic and anorganic } \\
\text { Materials }\end{array}$} & Moderate & $\alpha-$ Mesosaprobic & -1.0 up to -0.5 \\
\cline { 2 - 4 } & & $\alpha / \beta-$ Mesosaprobic & -0.5 up to 0.0 \\
\cline { 2 - 4 } & Light & $\beta / \alpha-$ Mesosaprobic & 0.0 up to +0.5 \\
\hline & & $\beta-$ Meso / oligo saprobic & +1.0 up to +1.5 \\
\hline $\begin{array}{c}\text { Organic and anorganic } \\
\text { Materials }\end{array}$ & \multirow{2}{*}{\begin{tabular}{c} 
Very Light \\
\cline { 2 - 4 }
\end{tabular}} & Oligo / $\beta-$ Meso Saprobic & +1.5 up to +2.0 \\
\hline
\end{tabular}




\section{Results}

\subsection{General Condition of the waters}

The locations for water sampling and periphyton were carried out at 4 station points in the upstream reaches of the Citarum River. The Station I was in the neighborhood Situ Cisanti, the station I have the characteristics of the water was murky colored greenish, the stream of water of the river is quiet. Station II is located in Wangisagara Village. The Community about using part of the river as a place to wash the motor. Part of the river is indicated affected waste agriculture such as fertilizers, pesticides, excrement of livestock and also waste the housing ladder. The water characteristic at station II is that it has a light brownish water color. Station III is located in Sukamaju Village, Majalaya District. Characteristics of the waters at station III which has the color of the water light brown and many found waste home stairs. Station IV is Kampung Sapan, Station IV covers the area after a meeting of three rivers, namely Sungai Citarum, river Citarik and rivers Cikerus. The characteristics of the waters at station IV are cloudy blackish. The following is an overview of the research location shown in (Figure 2).
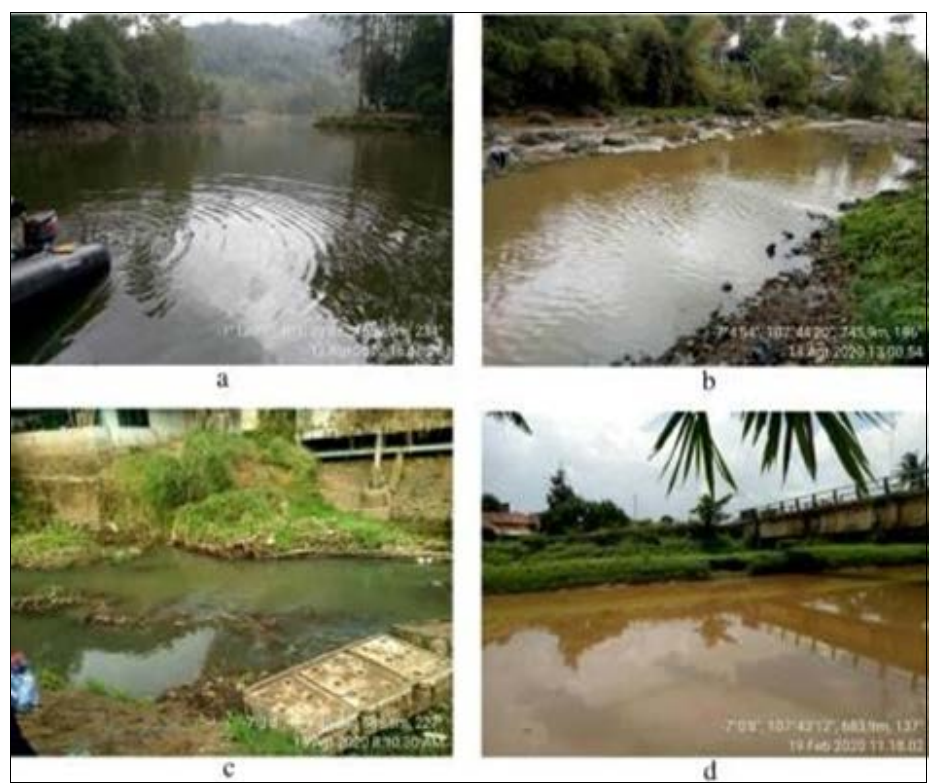

Fig 2: Overview of the Citarum River, a. Station I Outlet Situ Cisanti, b. Station II of Wangisagara Village, c. Station III Majalaya District, d. Station IV Sapan.

\subsection{Chemical physical parameters of Upstream Citarum River water}

Data from the observation of the physical and chemical parameters of the Upstream Citarum River water are shown in Table 2.

Table 2: Data of physical and chemical parameters of Upstream Citarum River Water

\begin{tabular}{|c|c|c|c|c|c|}
\hline \multirow{2}{*}{ Parameter Fisik } & \multicolumn{4}{|c|}{ Stasiun } \\
\cline { 2 - 6 } & & I & II & III & IV \\
\hline \multirow{2}{*}{ Temperature $\left({ }^{\circ} \mathrm{C}\right)$} & Range & $21,20-28,10$ & $21,10-29,40$ & $21,60-29,90$ & $23,60-27,60$ \\
\cline { 2 - 6 } & Average & $25,02 \pm 2,82$ & $25,12 \pm 2,81$ & $26,62 \pm 2,84$ & $26,63 \pm 1,52$ \\
\hline \multirow{2}{*}{ Light Transparency (cm) } & Range & $42,00-59,25$ & $11,70-61,00$ & $9,00-43,50$ & $15,25-49,50$ \\
\cline { 2 - 6 } & Average & $51,08 \pm 7,98$ & $39,58 \pm 18,39$ & $29,42 \pm 11,22$ & $29,71 \pm 13,38$ \\
\hline \multirow{2}{*}{ Current } & Range & $0,02-0,05$ & $0,21-0,25$ & $0,11-0,46$ & $0,23-0,46$ \\
\cline { 2 - 6 } & Average & $0,03 \pm 0,01$ & $0,21 \pm 0,04$ & $0,18 \pm 0,14$ & $0,31 \pm 0,09$ \\
\hline \multirow{2}{*}{$\mathrm{pH}$} & Range & $6,08-6,82$ & $6,21-6,81$ & $6,07-6,52$ & $6,23-6,45$ \\
\cline { 2 - 6 } & Average & $6,38 \pm 0,25$ & $6,37 \pm 0,23$ & $6,36 \pm 0,17$ & $6,32 \pm 0,10$ \\
\hline \multirow{2}{*}{$\mathrm{CO}(\mathrm{mg} / \mathrm{L})$} & Range & $2,61-4,35$ & $2,61-5,22$ & $3,48-6,09$ & $0,87-6,09$ \\
\cline { 2 - 6 } & Average & $3,62 \pm 0,85$ & $3,77 \pm 1,05$ & $4,35 \pm 1,10$ & $4,64 \pm 1,96$ \\
\hline \multirow{2}{*}{$\mathrm{DO}(\mathrm{mg} / \mathrm{L})$} & Range & $6,20-9,40$ & $6,70-8,00$ & $5,60-8,70$ & $6,10-7,80$ \\
\cline { 2 - 6 } & Average & $7,5 \pm 1,15$ & $7,48 \pm 0,73$ & $6,95 \pm 1,10$ & $6,92 \pm 0,61$ \\
\hline \multirow{2}{*}{$\mathrm{BOD}(\mathrm{mg} / \mathrm{L})$} & Range & $2,05-3,24$ & $0,87-3,95$ & $2,92-4,22$ & $1,95-6,48$ \\
\cline { 2 - 6 } & Average & $2,52 \pm 0,54$ & $2,52 \pm 1,2$ & $3,59 \pm 0,49$ & $4,47 \pm 1,68$ \\
\hline \multirow{2}{*}{ Nitrate (mg/L) } & Range & $0,22-0,22$ & $0,22-0,22$ & $0,22-0,23$ & $0,26-0,27$ \\
\cline { 2 - 6 } & Average & $0,22 \pm 0,002$ & $0,22 \pm 0,002$ & $0,23 \pm 0,003$ & $0,26 \pm 0,002$ \\
\hline \multirow{2}{*}{ Phosphate (mg/L) } & Range & $0,23-0,24$ & $0,24-0,25$ & $0,24-0,25$ & $0,25-0,26$ \\
\cline { 2 - 6 } & Average & $0,23 \pm 0,003$ & $0,24 \pm 0,001$ & $0,24 \pm 0,002$ & $0,25 \pm 0,001$ \\
\hline
\end{tabular}

The highest average temperature was at station IV which amounted to $26,63^{\circ} \mathrm{C} \pm 1.5$, the temperature of the low there at the station I which amounted to $25,02^{\circ} \mathrm{C} \pm 2,82$, with a range between $21,1^{\circ} \mathrm{C}-29,9^{\circ} \mathrm{C}$. The temperature of the Citarum
River for research increasingly towards downstream become increasingly high. Generally, the temperature decreases according to depth, this is related to the transparency of sunlight as a source of heat in water ${ }^{[7]}$. The intensity of the 
light of the sun is getting a lot to the area downstream, the exchange of heat between the water and air to the downstream is great so happened increase in temperature ${ }^{[8]}$. The optimum temperature for periphyton growth in the waters is in the temperature range of $20-30^{\circ} \mathrm{C}^{[9]}$. Temperatures were obtained during research in the Citarum River still supports periphyton to live. The highest average transparency light in the Citarum River at the time of the study there at station I amounted to $51,08 \mathrm{~cm} \pm 7,98$ and the lowest are in station III which amounted to $29,42 \pm 11,22 \mathrm{~cm}$, with the range between 9,00 $61,00 \mathrm{~cm}$. Differences transparency of light can be caused by a system to land and waste input are different each station has different turbidity. The concentration of solids suspended in water bodies resulting in the occurrence of turbidity so that the intensity of the light of the sun that enters into the body waters less than the maximum and the process of photosynthesis disturbed ${ }^{[10]}$. By the statement of Asrini et al. (2017), solids suspended like sand, soil clay, ingredients organic which were brought by waste more lots. The higher the suspended solids, the higher the turbidity value. If the turbidity is high, the oxygen content will decrease.

The highest average stream was at Stasium IV which amounted to $0,31 \mathrm{~m} / \mathrm{s} \pm 0,09$, and the lowest are in station I which amounted to $0,03 \mathrm{~m} / \mathrm{s} \pm 0,01$, with a range between $0,02-0,46 \mathrm{~m} / \mathrm{s}$. Streams are divided into the categories that currents are very fast $>1 \mathrm{~m} / \mathrm{s}$, fast $(0,50-1 \mathrm{~m} / \mathrm{s})$, medium $(0,25-0,50 \mathrm{~m} / \mathrm{s})$, slow $(0,10-0,25 \mathrm{~m} / \mathrm{s})$, and very slowly $(<0,10$ $\mathrm{m} / \mathrm{s}$ ). Stream of the Citarum River can be categorized into the stream very slowly until the stream medium.

The highest average acidity $(\mathrm{pH})$ was at Station I which amounted to $6,38 \pm 0,25$, and the lowest is in station IV which amounted to $6,32 \pm 0,10$, with a range between $6,07-6,82$. Acidity $(\mathrm{pH})$ is very closely related to the content of the metal weight that is in the river is getting a lot of material contaminants (the content of metals heavy) that are in the river then it will lead to a low value $(\mathrm{pH})$, which makes the hardness of the water is acidic, water that is classified as acidic because it is bicarbonate in water. High to low $\mathrm{pH}$ in water is also caused by the concentration of carbon dioxide (CO2). The more carbon dioxide produced from the respiration process, the lower the $\mathrm{pH}^{[11]}$. The $\mathrm{pH}$ value in the Region Stream Citarum River still relatively good views of Regulation Government of Number 82 Year 2001 concerning Management Quality of Water and Control of Pollution in connection with classification and criteria of standard quality of water waste class II, limit threshold $\mathrm{pH}$ that is intended for biota waters ranging from $\mathrm{pH}$ 6-9.

The highest Carbon Dioxide (CO2) content is at Station IV which amounted to $4,64 \mathrm{mg} / \mathrm{L} \pm 1,96$, while the lowest Carbon Dioxide (CO2) content is at Station I which amounted to $3,62 \mathrm{mg} / \mathrm{L} \pm 0,85$, in the range between 0,87 - 6,09 $\mathrm{mg} / \mathrm{L}$. Levels of carbon dioxide (CO2) which is good for the organism waters are less than $15 \mathrm{mg} / \mathrm{L}$. Anything more than that is very dangerous because it inhibits the binding of oxygen (O2) ${ }^{[12]}$. The more availability of carbon dioxide (CO2) in the waters will affect the organisms that carry out the respiration process while the lack of carbon dioxide (CO2) will affect the organisms in the photosynthetic process.

The highest average dissolved oxygen (DO) was at station I which amounted to $7,50 \mathrm{mg} / \mathrm{L} \pm 1,15$, while the oxygen dissolved lows are at Station IV which amounted to 6,92 $\mathrm{mg} / \mathrm{L} \pm 0,61$, with a range between $5,60-9,40 \mathrm{mg} / \mathrm{L}$. The content of oxygen dissolved in waters affected by the temperature, the higher the temperature of a water value of oxygen dissolved getting lower ${ }^{[13]}$. Getting to downstream DO is getting low. It is caused because the system to land at each station, getting to the downstream load of pollutants that enter into the waters is getting a lot. Human activities, such as agriculture and waste disposal, cause a decrease in dissolved oxygen concentrations ${ }^{[14]}$. Water can be said to be good and has a low level of pollution if its dissolved oxygen (DO) level is greater than $5 \mathrm{mg} / \mathrm{L}^{[15]}$. While the concentration of oxygen dissolved (DO) in the water that they naturally have a value of DO is less than $10 \mathrm{mg} / \mathrm{L}^{[10]}$. Value DO was acquired during the study still supports the life of organisms that exist in the Citarum River.

The highest average BOD was at Station IV which amounted to $4,76 \mathrm{mg} / \mathrm{L} \pm 1,62$, while the lowest average BOD was at Station II which amounted to $1,90 \mathrm{mg} / \mathrm{L} \pm 0,93$, with a range of $0,33-6,48 \mathrm{mg} / \mathrm{L}$. Higher levels of BOD, the more big also an indication that the water has been contaminated. Getting to downstream BOD is getting higher. It is caused because the system to land at each station, getting to the downstream load of pollutants that enter into the waters is getting a lot. Rising numbers of BOD can be derived from the material - material organic that comes from sewage domestic and wastes other [16]. Bodies that have a value of BOD of more than $10 \mathrm{mg} / \mathrm{L}$ are considered to have suffered contamination ${ }^{[17]}$.

The highest average nitrate was at Station IV which amounted to $0,26 \mathrm{mg} / \mathrm{L} \pm 0,002$, while the lowest average was at station I which amounted to $0,22 \mathrm{mg} / \mathrm{L} \pm 0,002$, with a range between $0,22 \mathrm{mg} / \mathrm{L}-0,27 \mathrm{mg} / \mathrm{L}$. Nitrates in the water resulting from the oxidation of nitrogen that is stable and easy to dissolve [10]. Nitrates can be used to clarify the level of fertility in waters. Bodies oligotrophic levels of nitrate of $0-1 \mathrm{mg} / \mathrm{L}$, aquatic mesotrophic levels of nitrate $1-5 \mathrm{mg} / \mathrm{L}$, water eutrophic levels of nitrate $5-50 \mathrm{mg} / \mathrm{L}^{[18]}$. Based on the results of research concentration of nitrate from 0,22 to $0,26 \mathrm{mg} / \mathrm{L}$, with such waters of the Citarum River included into the waters of oligotrophic.

The highest average phosphate was at Station IV which amounted to $0,25 \mathrm{mg} / \mathrm{L} \pm 0,001$, while the lowest average phosphate was at station I which amounted to $0,23 \mathrm{mg} / \mathrm{L} \pm$ 0,003 , with a range of between 0,23 to $0,26 \mathrm{mg} / \mathrm{L}$. The phosphate content in the water is influenced by industrial waste and domestic waste from the environment around the river ${ }^{[19]}$. The phosphate content in oligotrophic waters is 0,03-0,1 mg/L, mesotrophic waters are 0,11-0,3 mg/L and eutrophic waters are $0,31-1,0 \mathrm{mg} / \mathrm{L}^{[20]}$. Based on the results of the research of this, the concentration of phosphate in the Citarum River ranges from 0,23 to $0,25 \mathrm{mg} / \mathrm{L}$, by thus can be concluded waters of the Citarum River including waters mesotrophic. Nitrate and phosphate needed by phytoplanktonperiphyton in the number of the lot, so nitrates and phosphates into the factors limiting the growth of phytoplankton. This is related to differences in the tolerance of each type of phytoplankton-periphyton to the concentration of these nutrients ${ }^{[21]}$.

\subsection{Periphyton Saprobic Index}

Index saprobic is an index that is used to determine the status of contamination of organic in water. The Index is using the presence of organisms that are present in the water to determine the status of waters ${ }^{[5]}$. The saprobic index value of periphyton in the Citarum River during the research ranged from 0,69 to 1,00 . Calculation of the index saprobic periphyton was obtained during the research is presented in (Figure 3) below 


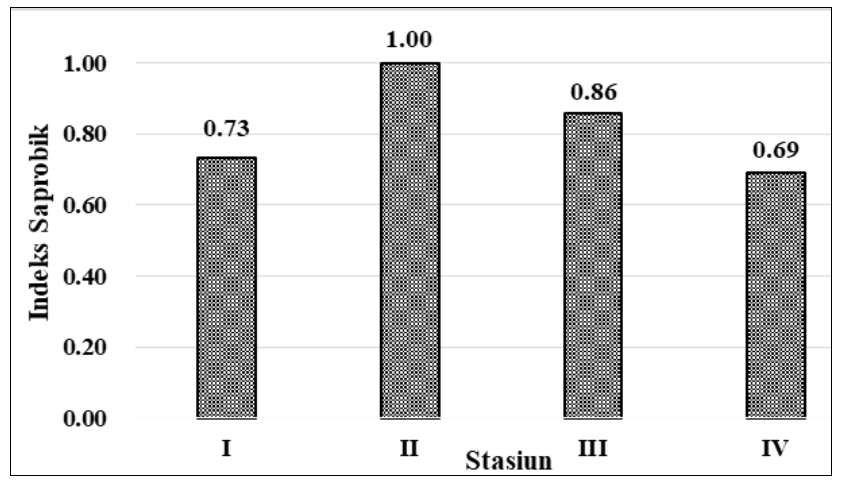

Fig 3: Periphyton Saprobic Index

Material pollutants with the index saprobic can be connected to the level of pollution of waters ${ }^{[6]}$. Station II has an index saprobic most high is at 1,00 which shows that the waters in station II have levels of contamination mild by category $\beta$ Mesosaprobic and the range of indices by 0,5-1,0. It is caused by the load of pollutants that enter into the waters of station II is still a little. A Load of pollutants enter into the waters of station II as fertilizers, pesticides, excrement of livestock, and also waste the housing ladder. The water characteristic at station II is that it has a light brownish water color. Station II has an index saprobic most low may mean that station II is water the most is not contaminated during the study. It is supported by the data Biochemical Oxygen Demand (BOD), which indicates that the station II has a BOD of the lowest among all stations. Station II has a moderate stream between all stations which makes the waste carry over to the next station.

Group periphyton which dominates in the waters of the station I was Chrysophyta. Chrysophyta is sensitive to changes in the aquatic environment. Sensitive nature allows Chrysophyta able to quickly respond and able to reflect changes in the quality of water ${ }^{[22]}$. The presence of diatoms from the Chrysophyta phylum, such as Nitzschia at all stations is thought to be an indicator of species in mild to moderately polluted waters. Nitzschia have a range of tolerance of contamination of materials of organic are spacious and can play a role as an indicator of the condition of waters were lightly polluted up polluted weight ${ }^{[23]}$.

Values index saprobic lows are in station IV is 0,69 which shows that the waters in station IV have the level of pollution light by category $\beta$ - Mesosaprobic and the range of indices by $0,5-1,0$. Group periphyton that dominates in the waters of station IV is Euglenophyceae and Bacillariophyceae. The low saprobic value at station IV is reinforced by the high value of Biochemical Oxygen Demand (BOD) at station IV. The existence of saprobic organisms as an indicator of water is also determined by the quality of the aquatic environment. Each type of saprobic organism will occupy certain waters and its existence is determined by the quality of the waters, namely the physical and chemical properties of the waters ${ }^{[24]}$.

\section{Conclusion}

The status of the upstream Citarum River has a mild level of pollution with periphyton saprobic index values ranging from 0,69 to 1,00 which is included in the $\beta$ - Mesosaprobic category. The quality of river water Citarum Part Hulu experienced the development of positive were significantly demonstrated by the increase in the concentration of oxygen dissolved and a decrease in the value of BOD.

\section{References}

1. Hendratta J, Sumarauw SF. “Analisis Debit Dan Tinggi Muka Air Sungai Tondano Di Jembatan Desa Kuwil Kecamatan Kalawat,” J Sipil Statik 2017;5(4):175-185.

2. (Kp3k-Dkp). (2009). Dirjen Kelautan, Perikanan, Dan Pulau-Pulau Kecil.

3. Azim E, Beveridge M, Van Dam J, Verdegem MCJ. "Periphyton And Aquatic Production: An Introduction," 2005.

4. Oktaviani Pratomo A, Idris F. "Pleurosigma Sp," 2016;1:1-12.

5. Sagala EP, Biologi J, Mipa F, Sriwijaya U. "Indek Saprobik Komunitas Dalam Menentukan Tingkat Pencemaran Di Perairan Laut Antara Muara Sungai Benu Dan Pulau Betet, Kabupaten Banyuasin, Propinsi Sumatera Selatan 2011;2:11-18.

6. Suwondo EF, Dessy AM. "Kualitas Biologi Perairan Sungai Senapelan, Sago Dan Sail Di Kota Pekanbaru Berdasarkan Bioindikator Plankton Dan Bentos,” J. Biog 2004, 15-20.

7. Pancawati DN, Purnomo PW, Studi P, Sumberdaya M, Perikanan J, Diponegoro U. "Karakteristik Fisika Kimia Perairan Habitat Bivalvia Di Sungai Wiso Jepara 2014;3:141-146.

8. Asrini NK, Adnyana IWS, Rai IN. "Studi Analisis Kualitas Air Di Daerah Aliran Sungai Pakerisan Provinsi Bali 2017, 101-107.

9. H. Effendi, Telaah Kualitas Air Bagi Pengelolaan Sumber Daya Dan Lingkungan Perairan. Jakarta: Kanisius, 2003.

10. Effendi H, Telaah Kualitas Air, Bagi Pengelolaan Sumber Daya Dan Lingkungan Perairan. Yogyakarta: Kanisius, 2003.

11. Barus TA, Pengantar Limnologi Studi Tentang Ekosistem Air Daratan. Medan: Usu Press, 2004.

12. Al Idrus SW. "Analisis Kadar Karbon Dioksida Di Sungai Ampenan Lombok Carbon Dioxide Concentration Analysis At Ampenan River Lombok,” 2018;13(2):167170.

13. Faturohman Sunarto I, Nurruhwati I. "Korelasi Kelimpahan Plankton Dengan Suhu Perairan Laut Di Sekitar Pltu Cirebon,” J Perikan. Kelaut 2016;1:115-122.

14. Blume KK, Macedo JC, Meneguzzi A, Silva LB, Quevedo DM, Rodrigues MAS. "Water Quality Assessment of The Sinos River, Southern Brazil," Brazilian J Biol 2010;70:4.

15. Salmin, "Oksigen Terlarut (Do) Dan Kebutuhan Oksigen Biologi (Bod) Sebagai Salah Satu Indikator Untuk Menentukan Kualitas Perairan,” Oseana 2005;30(3):2126,

16. Rahayu Tontowi S. "Penelitian Kualitas Air Bengawan Solo Pada Saat Musim Kemarau,” 2009;5(2):127-136.

17. Putra Zahidah AW, Lili W. "Struktur Komunitas Plankton Di Sungai Citarum Hulu Jawa Barat,” J Perikan. Dan Kelaut. Unpad 2012;3(4):313-325.

18. Mustofa A. "Kandungan Nitrat Dan Pospat Sebagai Faktor Tingkat Kesuburan Perairan Pantai,"

19. Disprotek 2015;6(1):13-19.

20. Patricia C, Astono W, Hendrawan DI. "Kandungan Nitrat Dan Fosfat Di Sungai Ciliwung,” Jur. Tek. Lingkung. Fak. Arsit. Lanskap Dan Teknol. Lingkung. Univ. Trisakti, 2018;4(1):179-185.

21. RG Wetzel, Limnology. Philadelphia: W. B. Sauders Company, 1975. 
22. Zahidah, Produktivitas Perairan. Bandung: Unpad Press, 2020.

23. Uswanto R, Purnomo S. "Keanekaragaman Fitoplanton Untuk Meninjau Kualitas Air Di Sungai Jagir,” 2020, 5157.

24. Aprisanti R, Mulyadi A, Siregar S. "Struktur Komunitas Diatom Epilitik Perairan Sungai Senapelan Dan Sungai Sail, Kota Pekanbaru Rizka Aprisanti,” J Ilmu Lingkung 2013;7(2):241-252.

25. Pringgosaputro S, "Studi Keterkaitan Antara Aktivitas Pembuangan Limbah Industri Dengan Tingkat Saprobitas Di Muara Sungai Sambong Kab. Dati Ii Batang (Sebagai Upaya Pendugaan Tingkat Pencemaran).," Lap. Penelitian. Pplh Lemlit Univ. Diponegoro, Semarang, 1993. 